УДК 598.233(571)

doi: $10.17223 / 19988591 / 37 / 7$

\title{
B.B. TapacoB
}

Институт экологии растений и животных УрО РАН, г. Екатеринбург, Россия

\section{Состояние красношейной поганки Podiceps auritus (Aves: Podicipediformes) в азиатской части России}

Работа выполнена в рамках проекта УрО РАН № 15-12-4-28.

На основании собственных данных и анализа литературных источников проведена ревизия состояния красношейной поганки Podiceps auritus (L.) 6 азиатской части РФ. Общая численность гнездовой популяиии этой территории составляет приблизительно 30-60 тыс. пар. Основная её часть (20-45 тыс. пар) сосредоточена в Западной Сибири, где вид местами ещё обычен, однако его численность здесь быстро снижсается: за последние два-три десятилетия она сократилась втрое. Столь быстрые темпы снижения численности вида требуют включить его в Красную книгу РФ и начать осуществлять срочные меры по его охране.

Ключевые слова: плотность гнездования; динамика численности; лимитирующие факторы; меры охраны.

\section{Введение}

Международный союз охраны природы в 2015 г. присвоил красношейной поганке Podiceps auritus (L.) категорию VU (уязвимый вид) на основании быстрого снижения её численности в Северной Америке и Европе. Ранее этот вид много лет не вызывал беспокойства (находился в категории LC). Но в течение последних 30 лет мировое население красношейной поганки сократилось на $30 \%$. В числе причин названы антропогенная деградация гнездовых местообитаний, в частности, вырубка деревьев вокруг лесных озёр, колебания уровня воды и выращивание радужной форели, конкурирующей с красношейной поганкой в питании за водных беспозвоночных. Кроме того, птицы гибнут в рыболовных сетях, уязвимы при разливах нефти на местах зимовок и для болезней. Мировая популяция вида оценивается в 239-583 тыс. особей [1], численность в Европе - в 6,4-9,2 тыс. пар, или 12,9-18,5 взрослой особи [2]. В Северной Америке численность каждые 10 лет снижается на 29,9\%, за последние 40 лет она статистически значимо уменьшилась на 75,9\%. Относительно небольшая европейская популяция сокращается со скоростью в $30 \%$ за 21,3 года (3 поколения).

В Евразии вид распространен от Скандинавии к востоку до бассейна Анадыря, Камчатки, Охотского побережья; к северу до устья Оби, в бассей- 
не Енисея до 61-й параллели, в бассейне Лены до 64-й, до долины среднего Анадыря; к югу до южного Алтая, юго-восточного Забайкалья, бассейна Амура; на Сахалине [3]. Площадь гнездового ареала в азиатской части РФ составляет 6,6 млн км² $($ по: $[1,4])$ - четверть площади мирового ареала. На протяжении $\mathrm{XX}$ в. в гнездовом ареале красношейной поганки в Европе произошли заметные изменения, вызванные в первую очередь эвтрофикацией озёр в результате деятельности человека [5]. В южных частях гнездового ареала численность её уменьшилась, а в северных - увеличилась. Так, до конца 1940-х гг. вид был обычен и даже многочислен на озёрах Барабинской лесостепи, где затем стал крайне редок [6]. На начало XXI в. численность в РФ оценивалась примерно в 55 тыс. особей [7].

Целью настоящей работы является анализ тренда численности популяций красношейной поганки и оценка их современного состояния в азиатских субъектах РФ.

\section{Урал}

На Южном Урале красношейная поганка была обычна в 1982-2006 гг. на озёрах лесостепи, реже встречалась на водоёмах горных и степных районов, общая численность вида оценивалась приблизительно в 4-5 тыс. гнездящихся пар [8]. Эти данные относятся почти целиком к Челябинской области, поскольку в соседних Оренбургской области и Республике Башкортостан вид крайне редок $[9,10]$. В национальном парке «Башкирия» за период 1996-2003 гг. зарегистрирована единственная пролётная особь [11], довольно редко вид встречается в Восточно-Уральском заповеднике [12].

На северо-востоке Челябинской области красношейная поганка обычна в окрестностях оз. Маян, где на сильно заросших участках озёр образует небольшие разреженные колонии, нередко совместно с другими поганками, крачками, чайками. Часто гнёзда встречаются и вне колоний [13]. Южнее, в Еткульском районе, в 1970-1980-х гг. вид был обычен или даже многочислен [14], а в 2014 г. здесь лишь на оз. Большой Сарыкуль обнаружены несколько особей [15]. В среднем за последние годы, по данным автора [15-17], плотность вида на водоёмах лесостепной части области составила около 0,6 пары/км² (от 0,3 до 0,9 ), а общая численность в этой части - примерно $1,2(0,6-1,8)$ тыс. гнездящихся пар. Таким образом, за 15-20 лет численность вида снизилась в три раза. В остальной части области (в горных и степных районах) сейчас обитает, по-видимому, не более 200 пар. Вместе с тем иногда встречаются и довольно крупные скопления птиц. Так, на небольшом оз. Чокарево в Увельском районе в июле 2015 г. наблюдали 300-400 взрослых поганок, многие из которых имели птенцов [18].

В более северных частях Урала вид встречается значительно реже. Точных данных по численности нет, но, как и для Южного Урала, имеются свидетельства её снижения, в частности, за 30 -летний период наблюдений на 
прудах у г. Верхнего Тагила [19]. На биостанции Уральского университета в окрестностях г. Екатеринбурга вид был обычен на лесных озёрах в конце 1970 -х гг., в 2000 г. численность упала в 4 раза, а в 2001 г. он вообще не обнаружен [20].

\section{Западная Сибирь}

В середине XX в. численность красношейной поганки была выше в лесной зоне Западной Сибири, чем в степной и лесостепной [21]. В 1980-х гг. в южном Зауралье она была повсеместно обычным, местами многочисленным гнездящимся видом, её обилие в лесостепи было на порядок выше, чем на юге лесной зоны [22]; наиболее оптимальные условия для размножения складывались в северной лесостепи - её обилие здесь составляло 18-65 особей/км² (на мелких заросших озёрах до 300 ), в южной лесостепи - около 12 особей/км²; в степной зоне была очень редка. Спустя 17 лет, в 2001 г., на тех же водоёмах в окрестностях г. Макушино Курганской области мы [23] нашли красношейную поганку гораздо более редкой $(0,1$ пары/км²), а на следующий год вообще не обнаружили [24]. К 2015 г. плотность на водоёмах частично восстановилась до 3 пар/км² [25]. Значительное падение численности (вплоть до исчезновения) наблюдали в 2000-х гг. и во многих других районах области [26, 27], за исключением лишь пойменных водоёмов в долине Тобола. Нужно заметить, что гидрологический цикл в конце 1990-х - начале 2000-х гг. находился в фазе повышенной водности: в эти годы, возможно, происходило перераспределение гнездящихся птиц с крупных озёр на вновь образовавшиеся мелкие лесные водоёмы, где они были гораздо менее заметны. Наряду со скрытным образом жизни это могло отразиться на результатах учётов. Общая численность вида в Курганской области в 1980-х гг., на основании экстраполяции данных Т.К. и В.Н. Блиновых [22, 28], составляла порядка 19 тыс. гнездящихся пар, сейчас - около 6 тыс. пар (таблица).

В полосе подтаёжных лесов среднелетний запас в 2006-2011 гг. оценивался приблизительно в 8 (3-20) тыс. особей, что в 10 раз меньше, чем в 1967-1982 гг. [29]. В южной тайге в 1990-1994 гг. такой запас составлял 21 (9-48) тыс. особей; по крайней мере, в Приобье и Прииртышье он снизился с конца 1960-х гг. в 1,3 раза [30]. В северной тайге Западной Сибири красношейная поганка зарегистрирована только в долине Оби, где её среднелетнее обилие в 1973 г. составляло порядка 2 (1-4) тыс. особей [31]. Обычна на гнездовании по р. Куноват [32], в Двуобье [33-35]. Наиболее северное место гнездования вида - лесотундра южного Ямала [36, 37]. Современная численность на территории ЯНАО, по-видимому, составляет порядка 0,51 тыс. пар (см. таблицу). В ХМАО красношейная поганка обычна на небольших укромных водоёмах с развитой водной растительностью в поймах Оби, Иртыша и более мелких рек [38]. Здесь гнездятся не менее 3 тыс. пар. В Березовском районе по Оби - одна из многочисленных гнездящихся птиц 
[39]. Обычна в Елизаровском заказнике [40], в окрестностях Нефтеюганска [41]. На междуречьях практически отсутствует. Редка в бассейне р. Большого Югана [42].

В Тюменской области в 1984-2005 гг. красношейная поганка была обычным гнездящимся видом поймы Тобола в Ярковском районе [43], в 1996 г. - также и на большинстве водоёмов в окрестностях г. Тюмени [44]. В 1982 г. населяла оз. Чертан у с. Озёрная в Ялуторовском районе с плотностью 7 особей/км ${ }^{2}$ [45]. В Казанском районе (лесостепь) в сезон 2007 г. нами [46] зарегистрирована единственная пара, как и в Армизонском в 2012 г. [47].

В Омской области в конце XX в. эта поганка населяла пресные озёра лесостепной и, вероятно, степной зоны, на заросших озёрах была обычна [48]. В частности, была обычна в Омском районе [49], гнездилась на пойменных водоёмах Иртыша и заливных лугах с плотностью 4-8 особей/км² [50]. На водоёмах Омска в 1986-1988 гг. в среднем за лето её плотность составляла 7 особей/км², а в 2006-2007 гг. она не встречена [51].

Редкий вид Томской области, гнездится на озёрах со сплавинами на Средней Кети [52]. В июне - июле 2008 г. зарегистрирован в среднем течении р. Андарма $(0,1$ особи/км²) в юго-восточной части Васюганского болота [53], гнездится также на притоках р. Томи [54]. Общая численность на Васюганском болоте, учитывая его огромные размеры (около 50 тыс. км²), может составлять 2-3 тыс. пар.

В Новосибирской области красношейная поганка довольно редка, распространена на гнездовании в основном в лесостепной и лесной зонах: в Карасукском, Каргатском, Венгеровском, Усть-Тарском районах, в пойме Оби ниже Новосибирска [55]. В Барабинской низменности в первой половине XX в. была обычна [56-58], с конца 1940-х гг. отмечено резкое ухудшение состояния популяции [6], в 1971-1976 гг. была очень редка, единичные особи встречались лишь на пролёте в районе оз. Чаны [59], в 1982-1988 гг. здесь снова оказалась обычна [60], но затем встречи стали крайне редки [55]. Вместе с тем в отдельных местах на севере области в 2005-2012 гг. наблюдали заметный рост численности [61].

В Кемеровской области вид занимает небольшие водоёмы, пойменные протоки и старицы в равнинной части, изредка встречается на горных озёрах Кузнецкого Алатау [62], найден на гнездовании на Пугачевских озёрах южнее г. Кемерово, в пойме Томи в Крапивинском районе, на Шестаковских болотах на востоке Чебулинского района, озёрах Большой Берчикуль и Малый Берчикуль на севере Тисульского района [63]. В равнинной части области - малочисленный гнездящийся вид [64], на водохранилищах в 1984-1994 гг. был обычен [65].

В Алтайском крае красношейная поганка очень редка, гнездование установлено на некоторых озёрах в Угловском районе [66, 67], в Баевском - на оз. Травное, в Быстроистокском - на озёрах Малое Камышное, Хвощёвое, Большое Карасевое, в Соколовском заказнике и предполагается ещё в целом ряде мест [68]. 
Ориентировочная численность красношейной поганки в субъектах азиатской части РФ и сведения о включении её в региональные Красные книги [Estimated numbers of the Horned Grebe in the regions of the Asian part of the Russian Federation and information about its inclusion in regional Red Data Books]

\begin{tabular}{|c|c|c|c|}
\hline $\begin{array}{c}\text { Субъект РФ } \\
\text { [Subject of the Russian Federation] }\end{array}$ & $\begin{array}{c}\text { Площадь } \\
\text { гнездового ареала, } \\
\text { тыс. км² } \\
\text { [Breeding area, } \\
\left.\text { thousand } \mathrm{km}^{2}\right]\end{array}$ & $\begin{array}{c}\text { Численность, тыс. } \\
\text { гнездовых пар } \\
\text { [Number, thousands } \\
\text { of breeding pairs] }\end{array}$ & $\begin{array}{c}\text { Категория в } \\
\text { региональной } \\
\text { Красной книге } \\
\text { [Category in the } \\
\text { regional Red Data } \\
\text { Book] }\end{array}$ \\
\hline $\begin{array}{l}\text { Челябинская область } \\
\text { [Chelyabinsk region] }\end{array}$ & 89 & $0,7-2$ & - \\
\hline $\begin{array}{l}\text { Свердловская область } \\
\text { [Sverdlovsk region] }\end{array}$ & 194 & $1-2$ & - \\
\hline $\begin{array}{l}\text { Курганская область } \\
\text { [Kurgan region] }\end{array}$ & 71 & $5-7$ & - \\
\hline $\begin{array}{l}\text { Ямало-Ненецкий АО } \\
\text { [Yamal-Nenets autonomous Okrug] }\end{array}$ & 50 & $0,5-1$ & - \\
\hline $\begin{array}{l}\text { Ханты-Мансийский АО } \\
\text { [Khanty-Mansiysk } \\
\text { autonomous Okrug] }\end{array}$ & 310 & $3-8$ & - \\
\hline $\begin{array}{l}\text { Тюменская область } \\
\text { [Tyumen region] }\end{array}$ & 280 & $4-10$ & - \\
\hline $\begin{array}{l}\text { Омская область } \\
\text { [Omsk region] }\end{array}$ & 141 & $2-6$ & - \\
\hline $\begin{array}{l}\text { Томская область } \\
\text { [Tomsk region] }\end{array}$ & 230 & $2-4$ & - \\
\hline $\begin{array}{l}\text { Новосибирская область } \\
\text { [Novosibirsk region] }\end{array}$ & 178 & $1-3$ & 3 \\
\hline $\begin{array}{l}\text { Кемеровская область } \\
\text { [Kemerovo region] }\end{array}$ & 96 & $0,5-1$ & 3 \\
\hline Алтайский край [Altay region] & 168 & $0,5-2$ & 3 \\
\hline $\begin{array}{l}\text { Республика Алтай } \\
\text { [Republic of Altay] }\end{array}$ & 50 & $0,1-0,3$ & - \\
\hline $\begin{array}{l}\text { Республика Хакасия } \\
\text { [Republic of Hakassia] }\end{array}$ & 62 & $0,3-0,5$ & 4 \\
\hline $\begin{array}{l}\text { Красноярский край } \\
\text { [Krasnoyarsk region] }\end{array}$ & 320 & $2-3$ & 4 \\
\hline $\begin{array}{l}\text { Республика Тыва } \\
\text { [Republic of Tyva] }\end{array}$ & 169 & $0-1$ & - \\
\hline $\begin{array}{l}\text { Иркутская область } \\
\text { [Irkutsk region] }\end{array}$ & 690 & $2-6$ & - \\
\hline $\begin{array}{l}\text { Республика Бурятия } \\
\text { [Republic of Buryatia] }\end{array}$ & 351 & $1-2$ & - \\
\hline $\begin{array}{l}\text { Забайкальский край } \\
\text { [Zabaykalskiy region] }\end{array}$ & 432 & $0,1-0,3$ & - \\
\hline $\begin{array}{l}\text { Республика Саха (Якутия) } \\
\text { [Republic of Sakha (Yakutia)] }\end{array}$ & 900 & $0,2-0,5$ & 3 \\
\hline $\begin{array}{l}\text { Амурская область } \\
\text { [Amur region] }\end{array}$ & 362 & $0-0,1$ & 2 \\
\hline $\begin{array}{l}\text { Хабаровский край } \\
\text { [Khabarovsk region] }\end{array}$ & 700 & $0-0,1$ & 3 \\
\hline $\begin{array}{l}\text { Еврейская AO } \\
\text { [Jewish Autonomous region] }\end{array}$ & 36 & $0-0,1$ & - \\
\hline $\begin{array}{l}\text { Сахалинская область } \\
\text { [Sakhalin region] }\end{array}$ & 87 & $0,3-0,8$ & - \\
\hline
\end{tabular}


О к о н ч а н и е т а б лицы [Table (end)]

\begin{tabular}{|l|c|c|c|}
\hline $\begin{array}{c}\text { Субъект РФ } \\
\text { [Subject of the Russian Federation] }\end{array}$ & $\begin{array}{c}\text { Площадь } \\
\text { гнездового ареала, } \\
\text { тыс. км }{ }^{2} \\
\text { [Breeding area, } \\
\text { thousand } \mathrm{km}^{2} \text { ] }\end{array}$ & $\begin{array}{c}\text { Численность, тыс. } \\
\text { гнездовых пар } \\
\text { [Number, thousands } \\
\text { of breeding pairs] }\end{array}$ & $\begin{array}{c}\text { Категория в } \\
\text { региональной } \\
\text { Красной книге } \\
\text { [Category in the } \\
\text { regional Red Data } \\
\text { Book] }\end{array}$ \\
\hline $\begin{array}{l}\text { Магаданская область } \\
\text { [Маgadan region] }\end{array}$ & 120 & $0,4-1$ & - \\
\hline $\begin{array}{l}\text { Камчатский край } \\
\text { [Kamchatka region] }\end{array}$ & 410 & $0,1-0,5$ & - \\
\hline $\begin{array}{l}\text { Чукотский AO } \\
\text { [Chukotka Autonomous okrug] }\end{array}$ & 100 & $0-0,1$ & - \\
\hline
\end{tabular}

В Республике Алтай в гнездовое время 2004 г. встречалась парами на небольших озёрах у подножия западной части хр. Сайлюгем, по долинам рек Калгуты и Аргамджи [69]. В Алтайском заповеднике в 1980-2000 гг. была обычна на лесных озёрах среднегорья, многочисленна на озёрах Джулукульской котловины [70].

В Хакасии численность гнездящейся группировки варьируется в пределах 0,68-1 тыс. особей, из них более $70 \%$ обитают в Усть-Абаканском, Таштыпском, Ширинском и Орджоникидзевском районах, остальные - в Аскизском, Бейском и Боградском. В 2005-2013 гг. численность вида уменьшилась, он исчез из большинства водоёмов степи и лесостепи [71].

\section{Восточная Сибирь и Дальний Восток}

Почти на всей территории Восточной Сибири и Дальнего Востока красношейная поганка редка, по-видимому, вследствие недостатка гнездовых местообитаний. На Енисее она распространена к северу до 61-й параллели [3], севернее до 1990-х гг. зарегистрированы три случайные встречи и одна в 1997 г. [72]. Численность вида в Красноярском крае не превышает 5-6 тыс. особей, из них более $65 \%$ населяют бассейн Ангары, среднего Чулыма и верхней Кети. Сравнительно обычен в Тоджинской котловине. Меньше этих поганок на лесных водоёмах ленточных боров правобережья Южно-Минусинской (15\%), Канской (7\%), Чулымо-Енисейской (5\%) и западной части Назаровской (3\%) котловин. На Подкаменной Тунгуске встречается фрагментарно. В последнее время происходит уменьшение обилия вида, особенно в южных и западных районах края, по-видимому, из-за беспокойства, вызванного освоением южно-таёжных и подтаёжных водоёмов [73]. В прошлом красношейная поганка была обыкновенна на гнездовании в западной части Минусинской котловины, где встречалась чаще, чем чомга [74], которая в региональную Красную книгу, в отличие от неё, не включена.

В Иркутской области красношейная поганка населяет преимущественно таёжные высокопродуктивные водоёмы. Она обычна в пойме р. Малая Анга, единичные особи и пары обнаружены на р. Киренга, в долинах рек 
Чона и Мура, бассейнах рек Зима и Ия, устье р. Иркут; изредка гнездится на озёрах Байкало-Ленского заповедника, Тажеранской степи и Крестовской пади; возможно, также в лесостепи Верхнего Приангарья [75]. В истоках и верхнем течении Ангары с 1983 по 2009 г. её численность заметно увеличилась [76]. Регулярно гнездится на городских водоёмах Иркутска, низовьев Иркута [77].

В Бурятии красношейная поганка редка, распространена по всей территории бассейна оз. Байкал, гнездится в долине Верхней Ангары, где ещё в 1983 г. была местами массовым видом [78, 79], на оз. Арангатуй, в пойме Селенги и, возможно, в устье Верхней Ангары и дельте Селенги [80]. В июле 2010 г. встречен выводок на р. Большой Чивыркуй в Баргузинском районе [81]. По-видимому, численность в республике снижается: в 1974-1975 гг. десятки пар гнездились колониями и поодиночке на нескольких озёрах в верховьях Витима [82], а в июне 2008 г. здесь встречена лишь одна пара [83].

Редка в Читинском районе Забайкальского края, гнездится в окрестностях оз. Шакшинское [84].

В Якутии красношейная поганка - редкий вид с ограниченным ареалом, населяет только ее южную часть [85]. Спорадично гнездится на озёрах Вилюйского бассейна и в долине Лены от пос. Кангалассы до устья Вилюя [8688], проникая, очевидно, из бассейна Енисея, на некоторых из них относительно обычна; известны залёты в бассейн среднего течения р. Колыма [89].

Сведений о гнездовании вида в Амурской, Еврейской областях, Хабаровском крае и на Чукотке почти нет. Так, в Амурской области они ограничены вековой давностью [90], когда красношейная поганка гнездилась в долине среднего течения Зеи и, возможно, Амура в Шимановском районе. На пролёте она отмечена на озёрах Зейско-Буреинской равнины [91] и Хинганского заповедника [92]. Вероятно, гнездового населения в области уже нет.

В Хабаровском крае красношейная поганка - редкий пролётный и, возможно, гнездящийся вид [93], отмечена в устье Уссури (Хабаровский район), пойме Амура в Нанайском районе, пойме Амгуни и на оз. Чукчагирское в районе им. Полины Осипенко, на реках Кур и Уда (Тугуро-Чумиканский район), оз. Болонь, побережье близ с. Аян (Аяно-Майский район), о-ве Большой Шантар и в заливе Чихачева [94].

На Сахалине эта поганка населяет его северную часть [95], где в целом редка [96]: гнездится в северо-восточной части на побережьях заливов Набильский, Пильтун, Чайво, в северо-западной - в устье р. Чёрная и на косе Кеми (залив Помрь), в северной - предположительно на озёрах в устье p. Большая (залив Байкал); обнаружена в Лунско-Набильском секторе [97]. В ряде заливов поселяется разреженными колониями [98], местами довольно обычна, в частности, в заливе Чайво, где на некоторых густо заросших травой озёрах образует поселения, насчитывающие до 40 пар [99].

В Магаданской области красношейная поганка гнездится на небольших сильно заросших лесотундровых озёрах равнинной части бассейна р. Кава, 
где не является редкостью, численность относительно стабильна $[100,101]$. В меньшем количестве гнездится на озёрах в пойме р. Чукча [102], на охотоморском побережье, в частности, в Малкачанской тундре [103] и, возможно, окрестностях Магадана [104, 105].

На Камчатке вид в целом малочислен [106], в мае на море наблюдаются стаи до двух десятков птиц, в период размножения более скрытен, чем серощёкая поганка. На севере Камчатки - малочисленный пролётный вид, факты гнездования не известны [107].

\section{Заключение}

Таким образом, общая численность гнездовой популяции красношейной поганки в азиатской части РФ сейчас составляет порядка 30-60 тыс. пар. Эта оценка примерно вдвое выше результата, полученного В.Г. Кривенко и В.Г. Виноградовым (2008), - 55 тыс. особей для всей территории РФ. Тем не менее анализ литературных источников и собственных данных подтверждает негативный тренд динамики численности вида в азиатской части РФ. Относительно высокая численность популяции (20-45 тыс. пар) сохраняется в Западной Сибири, где во многих местах вид ещё вполне обычен и даже многочислен, однако именно здесь, почти на всей её территории наиболее заметно сокращение численности вида: ещё 20-30 лет назад она была в три раза выше. В числе приоритетных мер охраны вида должно быть сохранение гнездовых местообитаний, в частности, запрет вырубки деревьев вокруг лесных озёр и ограничение разведения рыбы.

\section{Лumepamypa}

1. BirdLife International. Podiceps auritus. The IUCN Red List of Threatened Species 2016. URL: http://www.iucnredlist.org/details/22696606/0 (дата обращения: 07.03.2017).

2. BirdLife International. Species factsheet: Podiceps auritus 2017. URL: http://datazone. birdlife.org/userfiles/file/Species/erlob/supplementarypdfs/22696606_podiceps_auritus. pdf (дата обращения: 07.03.2017).

3. Степанян Л.С. Конспект орнитологической фауны СССР. М. : Наука, 1990. 728 с.

4. Рябицев B.К. Птицы Сибири: справочник-определитель: в 2 т. Москва ; Екатеринбург : Кабинетный учёный, 2014. Т. 1-2.

5. Курочкин Е.Н. Отряд Поганкообразные // Птицы СССР: История изучения. Гагары, Поганки, Трубконосые. М. : Наука, 1982. С. 333-351.

6. Кошелев А.И. Сезонные миграции поганок в районе озера Чаны (Западная Сибирь) // Миграции птиц в Азии. Новосибирск : Наука, 1977. С. 35-44.

7. Кривенко В.Г., Виноградов В.Г. Птицы водной среды и ритмы климата Северной Евразии. М. : Наука, 2008. 588 с.

8. Захаров В.Д. Птицы Южного Урала (видовой состав, распространение, численность). Екатеринбург; Миасс : ИГЗ УрО РАН, 2006. 228 с.

9. Давыгора А.В. Орнитологическая фауна Оренбургской области. Оренбург : изд-во ОГПУ, 2000. $84 \mathrm{c}$.

10. Валуев В.А., Валуев К.В. Кредким видам птиц Башкирии // Материалы к распространению птиц на Урале, в Приуралье и Западной Сибири. 2003. Вып. 8. С. 73-74. 
11. Торгашов O.A. Птицы национального парка «Башкирия» // Материалы к распространению птиц на Урале, в Приуралье и Западной Сибири. 2003. Вып. 8. C. $213-241$.

12. Тарасов О.В. Обзор орнитофауны Восточно-Уральского заповедника и сопредельных территорий // Материалы к распространению птиц на Урале, в Приуралье и Западной Сибири. 2004. Вып. 9. С. 166-177.

13. Кузьмич А.А., Попов С.В., Таушканов Е.А., Байнов А.А., Осипов М.А. Орнитофауна озера Маян и его окрестностей // Материалы к распространению птиц на Урале, в Приуралье и Западной Сибири. 2005. Вып. 10. С. 161-186.

14. Редько П.С. Птицы Еткульского района Челябинской области // Материалы к распространению птиц на Урале, в Приуралье и Западной Сибири. 1998. Вып. 3. C. $141-148$.

15. Тарасов B.В., Гашек В.А., Звигинщев C.E. К фауне птиц южной лесостепи Челябинской области // Материалы к распространению птиц на Урале, в Приуралье и Западной Сибири. 2014. Вып. 19. С. 142-153.

16. Тарасов В.В., Поляков В.Е., Давыдов А.Ю. К фауне птиц лесостепного северо-востока Челябинской области // Материалы к распространению птиц на Урале, в Приуралье и Западной Сибири. 2006. Вып. 11. С. 205-218.

17. Тарасов B.B., Грачёв С.В. Птицы Октябрьского района Челябинской области // Фауна Урала и Сибири. 2016. № 2. С. 191-204.

18. Гашек В.А. Новости орнитологического сезона 2015 года в лесостепи Челябинской области // Фауна Урала и Сибири. 2015. № 2. С. 44-47.

19. Пискунов А.Н. Птицы Верхнего Тагила и его окрестностей// Материалы к распространению птиц на Урале, в Приуралье и Западной Сибири. 1999. Вып. 4. С. 164-174.

20. Коровин B.A. Птицы биологической станции Уральского университета // Материалы к распространению птиц на Урале, в Приуралье и Западной Сибири. 2001. Вып. 6. C. $92-118$.

21. Гынгазов А.М., Миловидов С.П. Орнитофауна Западно-Сибирской равнины. Томск : изд-во Том. ун-та, 1977. 352 с.

22. Блинова Т.К., Блинов В.Н. Птицы Южного Зауралья: лесостепь и степь. Т. 1: Фаунистический обзор и охрана птиц. Новосибирск : Наука, 1997. 296 с.

23. Тарасов В.В., Рябицев В.К., Грехов Р.Г., Ляхов А.Г. К фауне птиц окрестностей Макушино // Материалы к распространению птиц на Урале, в Приуралье и Западной Сибири. 2001. Вып. 6. С. 160-166.

24. Тарасов В.В., Грехов Р.Г., Бологов И.О. Дополнения к фауне птиц окрестностей Макушино // Материалы к распространению птиц на Урале, в Приуралье и Западной Сибири. 2002. Вып. 7. С. 252-254.

25. Тарасов B.B., Поляков B.E. Дополнения к фауне птиц Макушинского района (Курганская область) // Фауна Урала и Сибири. 2015. № 2. С. 218-230.

26. Тарасов B.B. К состоянию редких видов птиц Курганской области // Материалы к распространению птиц на Урале, в Приуралье и Западной Сибири. 2011. Вып. 16. C. $110-139$.

27. Тарасов B.B. Озеро Большой Маньясс: 12 лет спустя // Материалы к распространению птиц на Урале, в Приуралье и Западной Сибири. 2012. Вып. 17. С. 155-164.

28. Блинова Т.К., Блинов В.Н. Птицы Южного Зауралья: лесостепь и степь. Т. 2: Территориальная неоднородность населения птиц и динамические процессы. Новосибирск : Наука. 1999. 288 с.

29. Торопов К.В., Бочкарева Е.Н. Птицы подтаёжных лесов Западной Сибири: 30-40 лет спустя. Новосибирск : Наука-Центр, 2014. 394 с.

30. Торопов К.B., Шор Е.Л. Птицы южной тайги Западной Сибири: 25 лет спустя. Новосибирск : Наука-Центр, 2012. 636 с. 
31. Bapmaneтов Л.Г. Птицы северной тайги Западно-Сибирской равнины. Новосибирск : Наука, 1998. 387 c.

32. Бахмутов B.A. Орнитофауна бассейна р. Куноват // Труды ИЭРиЖ УНЦ АН СССР. 1978. № 115. C. 64-70.

33. Головатин М.Г., Пасхальный С.П., Замятин Д.О. Летнее население птиц Двуобья в 2004-2005 годах // Материалы к распространению птиц на Урале, в Приуралье и Западной Сибири. 2004. Вып. 9. С. 69-75.

34. Локтионов Е.Ю., Пилипенко Д.В., Яковлев А.А. Птицы приобской северной тайги // Материалы к распространению птиц на Урале, в Приуралье и Западной Сибири. 2007. Вып. 12. С. 144-182.

35. Головатин М.Г., Пасхальный С.П. Птицы центральной части Двуобья // Материалы к распространению птиц на Урале, в Приуралье и Западной Сибири. 2008. Вып. 13. C. 26-30.

36. Пасхальный С.П., Головатин М.Г. Ландшафтно-зональная характеристика населения птиц полуострова Ямал. Екатеринбург : Изд-во Урал. ун-та, 2004. 79 с.

37. Мечникова С.А., Кудрявиев Н.В., Лузан П.И. Новые данные о распространении и динамике численности некоторых редких и малочисленных птиц на юге Ямала // Материалы к распространению птиц на Урале, в Приуралье и Западной Сибири. 2005. Вып. 10. С. 209-212.

38. Экология Ханты-Мансийского автономного округа / ред. В.В. Плотников. Тюмень : СофтДизайн, 1997. 288 с.

39. Венгеров М.П. Половой и возрастной состав водоплавающих птиц нижней Оби // Материалы VI Всесоюз. орнитол. конф. М. : МГУ, 1974. Ч. 2. С. 249-250.

40. Стрельников Е.Г. Состояние орнитофауны в Елизаровском заказнике летом 2001 года // Материалы к распространению птиц на Урале, в Приуралье и Западной Сибири. 2002. Вып. 7. С. 244-251.

41. Сульдин М.П. Птицы окрестностей Нефтеюганска // Материалы к распространению птиц на Урале, в Приуралье и Западной Сибири. 2003. Вып. 8. С. 176-193.

42. Стрельников Е.Г., Стрельникова О.Г. Краткие комментарии к распространению некоторых видов птиц в бассейне Большого Югана // Материалы к распространению птиц на Урале, в Приуралье и Западной Сибири. 1998. Вып. 3. С. 173-180.

43. Баянов E.C. Некоторые птицы Ярковского района Тюменской области // Материалы к распространению птиц на Урале, в Приуралье и Западной Сибири. 2007. Вып. 12. C. 13-20.

44. Граждан К.В. Птицы Тюмени и Тюменского района // Материалы к распространению птиц на Урале, в Приуралье и Западной Сибири. 1998. Вып. 3. С. 47-55.

45. Юдкин В.А. Птицы подтаёжных лесов Западной Сибири. Новосибирск : Наука, 2002. $488 \mathrm{c}$.

46. Тарасов В.В., Рябицев В.К., Примак И.В., Давыдов А.Ю. Птицы Казанского района Тюменской области // Материалы к распространению птиц на Урале, в Приуралье и Западной Сибири. 2007. Вып. 12. С. 238-258.

47. Тарасов В.В., Примак И.В. К состоянию неохраняемых редких видов птиц Тюменской области // Материалы ко второму изданию Красной книги Тюменской области. Тюмень : ТюменНИИгипрогаз, 2013. С. 125-144.

48. Якименко B.B. Материалы к распространению птиц в Омской области // Материалы к распространению птиц на Урале, в Приуралье и Западной Сибири. 1998. Вып. 3. C. $192-221$.

49. Соловьёв С.A. Орнитофауна города Омска и Омского района // Материалы к распространению птиц на Урале в Приуралье и Западной Сибири. 2001. Вып. 6. C. $147-153$.

50. Соловьёв С.А. Птицы Омска и его окрестностей. Новосибирск : Наука, 2005. 296 с. 
51. Соловьёв С.А., Одинцева А.А., Колпакова Т.Ю., Одиниев О.А., Соловьёв Ф.С., Яковлев K.A. Омск // Птицы городов России. М. : Товарищество научных изданий КМК, 2012. C. 331-360.

52. Москвитин С.С., Дубовик А.Д., Горд Б.Я. Птицы долины р. Кеть // Фауна и систематика позвоночных Сибири. Новосибирск : Наука, 1977. С. 245-279.

53. Миловидов С.П., Нехорошев О.Г., Куранов Б.Д. Птицы юго-восточной части Васюганского болота (Томская область) // Вестник Томского университета. Биология. 2014. № 2 (26). С. 108-129.

54. Миловидов С.П., Нехорошев О.Г., Куранов Б.Д. Птицы долин притоков реки Томи (Томская область) // Вестник Томского университета. Биология. 2015. № 4 (32). С. $91-$ 106.

55. Юрлов А.К. Поганка красношейная Podiceps auritus (Linnaeus, 1758) // Красная книга Новосибирской области. Животные, растения и грибы. 2-е изд. / ред.: В.А. Юдкин, Д.Н. Шауло. Новосибирск : Арта, 2008. 111 с.

56. Залесский И.М., Залесский П.М. Птицы юго-западной Сибири (зоогеографический обзор с указаниями новых данных о распространении) // Бюл. МОИП. Отд. биол. 1931. Т. 40, вып. 3/4. С. 145-206.

57. Рузский М.Д. Зоодинамика Барабинской степи // Тр. Том. ун-та. 1946. Т. 97. С. 17-68.

58. Янушевич А.И., Золотарёва О.С. Водоплавающая дичь Барабы. Новосибирск : Крайиздат, 1947.80 с.

59. Юрлов К.Т., Чернышов В.М., Кошелев А.И., Сагитов Р.А., Тотунов В.М., Ходков Г.И., Юрлов А.К. Новые и редкие птицы в районе озера Чаны (Западная Сибирь) // Миграции птиц в Азии. Новосибирск : Наука, 1977. С. 205-209.

60. Балацкий Н.Н. К авифауне озера Карачинского (Бараба) // Материалы к распространению птиц на Урале, в Приуралье и Западной Сибири. 1998. Вып. 3. С. 5-11.

61. Жуков B.C. Змееяд Circaetus gallicus, могильник Aquila heliaca и другие редкие птицы на севере Новосибирской области // Русский орнитологический журнал. 2012. Т. 21, экспресс-вып. 792. С. 2149-2161.

62. Васильченко А.А. К орнитофауне северо-востока Кемеровской области // Материалы к распространению птиц на Урале, в Приуралье и Западной Сибири. 2005. Вып. 10. C. $55-103$.

63. Гагина Т.Н., Скалон Н.В., Ильяменко В. Б. Поганка красношейная, или рогатая // Красная книга Кемеровской области: Т. 2: Редкие и находящиеся под угрозой исчезновения виды животных / ред. Н.В. Скалон. Кемерово : Азия принт, 2012. С. 94-96.

64. Белянкин А.Ф. Птицы равнинной части Кемеровской области // Материалы к распространению птиц на Урале, в Приуралье и Западной Сибири. 1999. Вып. 4. С. $14-43$.

65. Головина H.M. Гнездящаяся авифауна водохранилищ Кемеровской области (Неворобьиные) // Материалы к распространению птиц на Урале, в Приуралье и Западной Сибири. 2006. Вып. 11. С. 51-57.

66. Котлов А.А., Гармс О.Я. Список птиц Угловского района Алтайского края // Материалы к распространению птиц на Урале, в Приуралье и Западной Сибири. 2007. Вып. 12. C. $124-137$.

67. Котлов А.А. К распространению редких птиц на юго-западе Кулунды // Алтайский зоологический журнал. 2015. Вып. 9. С. 69-71.

68. Петров В.Ю., Вотинов А.Г. Красношейная поганка - Podiceps auritus (Linnaeus, 1758) // Красная книга Алтайского края. Редкие и находящиеся под угрозой исчезновения виды животных / ред.: Н. Л. Ирисова, Е. В. Шапетько. Т. 2. Барнаул : Изд-во Алт. ун-та, 2016. С. 114-115.

69. Грибков А.В., Гармс О.Я., Рябищев В.К., Рябицев А.В. К фауне птиц хребта Сайлюгем и его окрестностей (Юго-Восточный Алтай) // Русский орнитологический журнал. 2010. Т. 19, экспресс-вып. 593. С. 1515-1561. 
70. Митрофанов О.Б. Некоторые особенности распределения водоплавающих на территории Алтайского заповедника // Проблемы изучения и охраны гусеобразных птиц Восточной Европы и Северной Азии : тез. докл. I совещ. рабочей группы по гусям и лебедям. М., 2001. С. 88-89.

71. Савченко А.П., Емельянов В.И. Красношейная поганка // Красная книга Республики Хакасия: Редкие и находящиеся под угрозой исчезновения виды животных / ред. А.П. Савченко. Красноярск; Абакан : Наука, 2014. С. 93-94.

72. Бурский О.В., Пагенкопф К., Ворстмайер В. Птицы Среднего Енисея: аннотированный список видов // Материалы к распространению птиц на Урале, в Приуралье и Западной Сибири. 2003. Вып. 13. С. 48-71.

73. Савченко А.П., Емельянов В.И. Красношейная поганка // Красная книга Красноярского края. Т. 1. Редкие и находящиеся под угрозой исчезновения виды животных. 3-е изд. / ред. А.П. Савченко. Красноярск : Изд-во Краснояр. ун-та, 2012. С. 51.

74. Рогачёва Э.В. Птицы Средней Сибири. М. : Наука, 1988. 309 с.

75. Попов B.B. Птицы Иркутской области: видовой состав, распространение и характер пребывания. Гагарообразные - журавлеобразные // Байкальский зоологический журнал. 2012. № 1 (9). С. 36-62.

76. Мельников Ю.И. Ключевая орнитологическая территория международного значения: Исток и верхнее течение р. Ангары // Байкальский зоологический журнал. 2010. № 1 (4). С. 41-46.

77. Сонина М.В. Эколого-фаунистический обзор гнездящихся птиц города Иркутска // Байкальский зоологический журнал. 2009. № 3. С. 84-87.

78. Мельников Ю.И., Таничев А.И., Жаров В.А. Поганки среднего течения Верхней Ангары // Русский орнитологический журнал. 1997. Т. 6, экспресс-вып. 30. С. 18-20.

79. Подковыров В.A. Очерк по биологии гагар и поганок юга Восточной Сибири // Орнитологические исследования в России / ред. Ц.З. Доржиев. Улан-Удэ : Изд-во Бурят. ун-та, 2000. Вып. 2. С. 120-147.

80. Государственный кадастр объектов животного мира в пределах Республики Бурятия. URL: http://www.minpriroda-rb.ru/redbook/kadastr-obektov-zhivotnogo-mira. php?ELEMENT_ID=34265 (дата обращения: 07.03.2017).

81. Вержуцикий Д.Б. И. Интересные встречи птиц в Республике Бурятия // Байкальский зоологический журнал. 2014. № 2 (15). С. 59-62.

82. Шкатулова А.П. Материалы по орнитофауне Бурятской АССР // Орнитология. 1979. Вып. 14. С. 97-107.

83. Попов В.В., Ананин А.А. Заметки по орнитофауне Еравнинских озёр и их окрестностей (Бурятия). Неворобьиные // Байкальский зоологический журнал. 2009. № 2. С. 71-79.

84. Миронова B.E., Перетолчина Т.А. Летняя орнитофауна системы Ивано-Арахлейских озёр // Учён. зап. Забайкал. ун-та. Сер.: Естественные науки. 2010. Вып. 1. С. 147-151.

85. Воробьёв К.А. Птицы Якутии. М. : изд-во АН СССР, 1963. 336 с.

86. Маак Р.К. Вилюйскій округъ Якутской Области. СПб. : Тип. и хромолит. А. Траншеля, 1886. Ч. 2. 368 c.

87. Андреев Б.Н. Птицы Вилюйского бассейна. Якутск : Якут. кн. изд-во, 1987. 192 с.

88. Вартапетов Л.Г., Гермогенов Н.И. Анализ фауны и классификация населения птиц долины средней Лены // Зоологический журнал. 2013. Т. 92, № 1. С. 77-86.

89. Красная книга Республики Саха (Якутия). Т. 2: Редкие и находящиеся под угрозой исчезновения виды животных (насекомые, рыбы, земноводные, пресмыкающиеся, птицы, млекопитающие) / ред. В.Г. Алексеев. Якутск, 2003. 208 с.

90. Stegmann B.K. Die Vogel des Dauro-mandschurischen Uebergangsgebietes // J. fur Ornithologie. 1930. Jg. 78, heft 4. P. 389-471.

91. Дугинщов B.A., Панькин Н.С. Список птиц Верхнего и Среднего Приамурья в административных границах Амурской области // Проблемы экологии верхнего Приамурья : сб. науч. тр. Благовещенск, 1993. С. 120-140. 
92. Антонов А.И., Парилов М.П. К оценке современного статуса охраняемых видов птиц на востоке Амурской области // Амурский зоологический журнал. 2009. Т. 1, № 3. C. $270-274$.

93. Бабенко В.Г. Птицы Нижнего Приамурья. М. : Прометей, 2000. 724 с.

94. Росляков А.Г. Красношейная поганка // Красная книга Хабаровского края: Редкие и находящиеся под угрозой исчезновения виды растений и животных / ред. В.И. Ишаев. Хабаровск : Приамурские ведомости, 2008. С. 417-418.

95. Нечаев B.A. Красношейная поганка // Красная книга Амурской области: Редкие и находящиеся под угрозой исчезновения виды животных, растений и грибов / ред. О.Н. Кожемяко. Благовещенск : Изд-во Благовещ. пед. ун-та, 2009. 52 с.

96. Тиунов И.М., Блохин А.Ю. Редкие и малочисленные виды птиц Северного Сахалина (новые встречи) // Русский орнитологический журнал. 2012. Т. 21, экспресс-вып. 827. C. 3192-3198.

97. Глущенко Ю.Н., Кальниикая И.Н., Коробов Д.В. Птицы Лунско-Набильского сектора Северо-Восточного Сахалина. Сообщение 1: Фоновое население // Амурский зоологический журнал. 2012. T. IV, № 1. С. 83-96.

98. Блиновская Я.Ю., Бочарников В.Н. Птицы в экосистемах морского побережья как индикатор чувствительности прибрежно-морской зоны к нефтяному загрязнению // Защита окружающей среды в нефтегазовом комплексе. 2008. № 2. С. 35-39.

99. Сурмач Н., Вальчук О. Птицы Сахалина. Владивосток : Апельсин, 2010. 156 с.

100. Андреев А.В., Кречмар А.В., Утехина И.Г. Птицы // Растительный и животный мир заповедника «Магаданский». Магадан : СВНЦ ДВО РАН, 2011. С. 129-155.

101. Кречмар A.B. Гагары Gaviiformes и поганки Podicipitiformes кавинской равнинной лесотундры (северное Приохотье) // Вестник СВНЦ ДВО РАН. 2013. № 1. С. 60-68.

102. Кавинская равнина и озеро Чукча. URL: http://www.fesk.ru/wetlands/277.html (дата обращения: 07.03.2017).

103. Андреев A.B. Природные условия участков заповедника // Растительный и животный мир заповедника «Магаданский». Магадан : СВНЦ ДВО РАН, 2011. С. 6-46.

104. Дорогой И.В. Водоплавающие и другие околоводные птицы окрестностей Ольской лагуны // Вестник СВНЦ ДВО РАН. 2008. № 4. С. 45-62.

105. Дорогой И.В. Авифаунистические находки на юге Магаданской области // Вестник СВНЦ ДВО РАН. 2010. № 4. С. 37-44.

106. Камчатка: справочник туриста / ред. В.И. Кириллов и др. ПетропавловскКамчатский : Дальневост. кн. изд-во, 1994. 228 с.

107. Завгарова Ю.Р., Герасимов Ю.Н., Сыроечковский Е.Е., Лаппо Е.Г., Хелквист А., Пальмер Ф., Бухалова Р.В. Птицы окрестностей посёлка Ильпырского (крайний юго-запад Корякского нагорья) // Биология и охрана птиц Камчатки. 2014. Вып. 10. C. $3-32$.

Поступила в редакиию 28.02.2017 г.; повторно 06.03.2017 г.; принята 07.03.2017 г.; опубликована 25.03.2017 г.

\section{Сведения об авторе:}

Тарасов Владимир Васильевич - канд. биол. наук, доцент, с.н.с. лаборатории экологии птиц и наземных беспозвоночных Института экологии растений и животных УрО РАН (Россия, 620144, г. Екатеринбург, ул. 8 Марта, 202).

E-mail: grouse@bk.ru

Tarasov VV. The current status of Asian populations of the Horned Grebe Podiceps auritus (Aves: Podicipediformes) in Russia. Vestnik Tomskogo gosudarstvennogo universiteta. Biologiya - Tomsk State University Journal of Biology. 2017;37:122-143. doi: 10.17223/19988591/37/7 In Russian, English summary 


\section{Vladimir V. Tarasov}

Institute of Plant and Animal Ecology, Ural branch, Russian Academy of Sciences, Yekaterinburg, Russian Federation

\section{The current status of Asian populations of the Horned Grebe Podiceps auritus (Aves: Podicipediformes) in Russia}

The author presents the results of analysis of the current status of Asian populations of Horned Grebes Podiceps auritus (L.) based on his own studies and the published data. This work is part of the preparation of the next edition of the Red Data Book of the Russian Federation. The state of the world Horned Grebe population had not caused concern for many years, but in 2015, the Horned Grebe was included in the IUCN Red List of Threatened Species and assigned the VU (Vulnerable Species) category because of a rapid decline in the species' numbers in North America and Europe.

Despite the voluminous published data on the Horned Grebe, precise information on the species' population dynamics in some regions of the Russian Federation is very scarce. A few publications feature estimated numbers achieved by extrapolation of the species' density data, but usually the authors would just give grade definitions like "common", "numerous" or "rare". Therefore, our quantitative estimation of the Horned Grebe breeding population in the Asian part of Russia is quite rough: 30-60 thousand pairs. The species' breeding area in that territory is about 6.6 million $\mathrm{km}^{2}$ or $25 \%$ of its world range area. Presuming that the species breeds with the same average density (5-9 pairs / thousand $\mathrm{km}^{2}$ ) in the rest of its range as in the Asian part of Russia, we may estimate the world Horned Grebe population at the same numbers as in the IUCN Red List of Threatened Species (Version 2016-3) (239-583 thousand individuals).

The largest species' resources are located in the Trans-Urals and the western part of Western Siberia (Kurgan, Tyumen, Omsk regions and the Khanty-Mansiysk autonomous okrug). Eastward of that territory the abundance of the Horned Grebe reduces significantly. The few data on the species' population dynamics in the Trans-Urals and the western part of Western Siberia show that the population in that area decreased by $70 \%$ over the last two or three decades. Those regions are now breeding grounds for more than a half of the Asian population of the Horned Grebe in Russia (16-36 thousand pairs). The average species' density there is $14-36$ pairs / thousand $\mathrm{km}^{2}$. As for the vast territory of Eastern Siberia and the Far East featuring mostly mountainous landscape, the Horned Grebe is very rare there (probably due to insufficiency of breeding habitats) and nests with a much lower density (1-3 pairs / thousand $\mathrm{km}^{2}$ ) while its total numbers in that area are 7-15 thousand pairs. Some breeding areas of the species observed for a relatively long period of time also show a negative trend in the population abundance. All these data provide sufficient grounds for governmental protection of the species and its inclusion in the Red Data Book of the Russian Federation. However, it is necessary to point out the widespread decrease in the species' numbers even in areas with no anthropogenic activity which shows that the reasons behind the abundance reduction are global and have not only been anthropologically induced. Possibly, there are other factors affecting the species' migrations and wintering. Priority measures for the species protection are conservation of breeding habitats, particularly restriction of forest felling and fish farming around forest lakes.

The article contains 1 Table, 107 References.

Key words: nesting density; population dynamics; limiting factors; protective measures. 
Fundings: The study was financed by the project of the Ural Branch of the Russian Academy of Sciences (No 15-12-4-28).

\section{References}

1. BirdLife International. Podiceps auritus. The IUCN Red List of Threatened Species. 2016 [Electronic resource]. Available at: http://www.iucnredlist.org/details/22696606/0 (accessed 07.03.2017)

2. BirdLife International. Species factsheet: Podiceps auritus. 2017 [Electronic resource]. Available at: http://datazone.birdlife.org/userfiles/file/Species/erlob/supplementarypdfs/ 22696606_podiceps_auritus.pdf (accessed 07.03.2017)

3. Stepanyan LS. Konspekt ornitologicheskoy fauny SSSR [Summary of the avifauna of the USSR]. Moscow: Nauka Publ.; 1990. 728 p. In Russian

4. Ryabitsev VK. Ptitsy Sibiri: spravochnik-opredelitel' [The birds of Siberia: an Identification Guide]. Vol. 1-2. Moscow; Yekaterinburg: Kabinetnyy uchenyy Publ.; 2014. 890 p. In Russian

5. Kurochkin EN. Otryad Pogankoobraznye [The Podicipediformes]. In: Ptitsy SSSR: Istoriya izucheniya. Gagary, Poganki, Trubkonosye [The birds of the USSR: History of studies. Loons, Grebes, Tube-nosed birds]. Moscow: Nauka Publ.; 1982. pp. 333-351. In Russian

6. Koshelev AI. Sezonnye migratsii poganok v rayone ozera Chany (Zapadnaya Sibir') [Seasonal Grebe migrations in the area of Chany Lake (Western Siberia)]. In: Migratsii ptits $v$ Azii [Bird migrations in Asia]. Novosibirsk: Nauka, Siberian Branch Publ.; 1977. pp. 35-44. In Russian

7. Krivenko VG, Vinogradov VG. Ptitsy vodnoy sredy i ritmy klimata Severnoy Evrazii [The aquatic birds and climatic rhythms of Northern Eurasia]. Moscow: Nauka Publ.; 2008. 588 p. In Russian

8. Zakharov VD. Ptitsy Yuzhnogo Urala (vidovoy sostav, rasprostranenie, chislennost') [Birds of the Southern Urals (species composition, distribution, abundance)]. Yekaterinburg; Miass: Ilmen State Nature Reserve of the Ural Branch of the Russian Academy of Sciences Publ.; 2006. 228 p. In Russian

9. Davygora AV. Ornitologicheskaya fauna Orenburgskoy oblasti [The avifauna of Orenburg region]. Orenburg: Orenburg State Pedagogical University Publ.; 2000. 84 p. In Russian

10. Valuev VA, Valuev KV. K redkim vidam ptits Bashkirii [On the rare bird species of Bashkiriya]. Materialy k rasprostraneniyu ptits na Urale, v Priural'e i Zapadnoy SibiriMaterials on the bird distributions in the Urals, Cisurals and Western Siberia. 2003;8:7374. In Russian

11. Torgashov OA. Ptitsy natsional'nogo parka "Bashkiriya" [The birds of the National Park "Bashkiriya"]. Materialy k rasprostraneniyu ptits na Urale, v Priural'e i Zapadnoy SibiriMaterials on the bird distributions in the Urals, Cisurals and Western Siberia. 2003;8:213241. In Russian

12. Tarasov OV. Obzor ornitofauny Vostochno-Ural'skogo zapovednika i sopredel'nyh territoriy [Survey of the avifauna of the Eastern Ural Nature Reserve and the adjacent territories]. Materialy $k$ rasprostraneniyu ptits na Urale, v Priural'e i Zapadnoy Sibiri - Materials on the bird distributions in the Urals, Cisurals and Western Siberia. 2004;9:166-177. In Russian

13. Kuz'mich AA, Popov SV, Taushkanov EA, Baynov AA, Osipov MA. Ornitofauna ozera Mayan i ego okrestnostey [The avifauna of Mayan Lake and its vicinity]. Materialy $k$ rasprostraneniyu ptits na Urale, $v$ Priural'e i Zapadnoy Sibiri-Materials on the bird distributions in the Urals, Cisurals and Western Siberia. 2005;10:161-186. In Russian 
14. Red'ko PS. Ptitsy Etkul'skogo rayona Chelyabinskoy oblasti [The birds of the Etkul district of Chelyabinsk region]. Materialy $k$ rasprostraneniyu ptits na Urale, $v$ Priural'e $i$ Zapadnoy Sibiri-Materials on the bird distributions in the Urals, Cisurals and Western Siberia. 1998;3:141-148. In Russian

15. Tarasov VV, Gashek VA, Zvigintsev SE. On the avifauna of the southern forest steppe of Chelyabinsk region. Materialy $k$ rasprostraneniyu ptits na Urale, v Priural'e $i$ Zapadnoy Sibiri - Materials on the bird distributions in the Urals, Cisurals and Western Siberia. 2014;19:142-153. In Russian

16. Tarasov VV, Polyakov VE, Davydov AYu. K faune ptits lesostepnogo severo-vostoka Chelyabinskoy oblasti [On the avifauna of the forest steppe northeast of Chelyabinsk region]. Materialy $k$ rasprostraneniyu ptits na Urale, v Priural'e i Zapadnoy Sibiri Materials on the bird distributions in the Urals, Cisurals and Western Siberia. 2006;11:205218. In Russian

17. Tarasov VV, Grachev SV. Birds of the Oktyabrskoe district of Chelyabinsk region. Fauna Urala $i$ Sibiri [Fauna of the Urals and Siberia]. 2016;2:191-204. In Russian, English summary

18. Gashek VA. News of the 2015 ornithological season from the forest steppe of the Chelyabinsk region. Fauna Urala i Sibiri [Fauna of the Urals and Siberia]. 2015;2:44-47. In Russian, English summary

19. Piskunov AN. Ptitsy Verhnego Tagila i ego okrestnostey [The birds of Verhniy Tagil and its surroundings]. Materialy k rasprostraneniyu ptits na Urale, $v$ Priural'e i Zapadnoy Sibiri Materials on the bird distributions in the Urals, Cisurals and Western Siberia. 1999;4:164174. In Russian

20. Korovin VA. Ptitsy biologicheskoy stantsii Ural'skogo universiteta [The birds of the Ural University Biological Station]. Materialy k rasprostraneniyu ptits na Urale, v Priural'e $i$ Zapadnoy Sibiri - Materials on the bird distributions in the Urals, Cisurals and Western Siberia. 2001;6: 92-118. In Russian

21. Gyngazov AM, Milovidov SP. Ornitofauna Zapadno-Sibirskoy ravniny [The avifauna of the West Siberian Plain]. Tomsk: Tomsk University Publ.; 1977. 352 p. In Russian

22. Blinova TK, Blinov VN. Ptitsy Yuzhnogo Zaural'ya: lesostep' i step'. T. 1. Faunisticheskiy obzor i ohrana ptits [The birds of the Southern Trans-Urals: Forest steppe and steppe. Vol. 1. Faunistic survey and protection of the birds]. Novosibirsk: Nauka, Siberian Branch Publ.; 1997. 296 p. In Russian

23. Tarasov VV, Ryabitsev VK, Grehov RG, Lyahov AG. K faune ptits okrestnostey Makushino [On the avifauna of Makushino village surroundings]. Materialy $k$ rasprostraneniyu ptits na Urale, $v$ Priural'e i Zapadnoy Sibiri-Materials on the bird distributions in the Urals, Cisurals and Western Siberia. 2001;6:160-166. In Russian

24. Tarasov VV, Grehov RG, Bologov IO. Dopolneniya k faune ptits okrestnostey Makushino [Additions to the avifauna of Makushino village surroundings]. Materialy k rasprostraneniyu ptits na Urale, v Priural'e i Zapadnoy Sibiri - Materials on the bird distributions in the Urals, Cisurals and Western Siberia. 2002;7:252-254. In Russian

25. Tarasov VV, Polyakov VE. Additions to the bird fauna of Makushino district (Kurgan region). Fauna Urala i Sibiri [Fauna of the Urals and Siberia]. 2015;2:218-230. In Russian, English summary

26. Tarasov VV. K sostoyaniyu redkih vidov ptits Kurganskoy oblasti [On the state of the rare bird species in Kurgan region]. Materialy $k$ rasprostraneniyu ptits na Urale, $v$ Priural'e $i$ Zapadnoy Sibiri-Materials on the bird distributions in the Urals, Cisurals and Western Siberia. 2011;16:110-139. In Russian

27. Tarasov VV. Ozero Bol'shoy Man'yass: 12 let spustya [Bolshoy Manyass Lake: 12 years later]. Materialy k rasprostraneniyu ptits na Urale, $v$ Priural'e i Zapadnoy Sibiri-Materials on the bird distributions in the Urals, Cisurals and Western Siberia. 2012;17:155-164. In Russian 
28. Blinova TK, Blinov VN. Ptitsy Yuzhnogo Zaural'ya: lesostep' i step'. T. 2. Territorial'naya neodnorodnost' naseleniya ptits i dinamicheskie protsessy [The birds of the Southern TransUrals: forest steppe and steppe. Vol. 2. The territorial heterogeneity of the bird population and dynamic processes]. Novosibirsk: Nauka, Siberian Branch Publ.; 1999. 288 p. In Russian

29. Toropov KV, Bochkareva EN. Ptitsy podtaezhnyh lesov Zapadnoy Sibiri: 30-40 let spustya [The birds of the subtaiga forests of Western Siberia: 30-40 years later]. Novosibirsk: Nauka-Tsentr Publ.; 2014. 394 p. In Russian

30. Toropov KV, Shor EL. Ptitsy yuzhnoy taygi Zapadnoy Sibiri: 25 let spustya [The birds of the southern taiga of Western Siberia: 25 years later]. Novosibirsk: Nauka-Tsentr Publ.; 2012. 636 p. In Russian

31. Vartapetov LG. Ptitsy severnoy taygi Zapadno-Sibirskoy ravniny [The birds of the northern taiga of the West Siberian Plain]. Novosibirsk: Nauka, Siberian Branch Publ.; 1998. 387 p. In Russian

32. Bahmutov VA. Ornitofauna basseyna r. Kunovat [The avifauna of the Kunovat River basin]. Trudy Instituta ekologii rasteniy i zhivotnyh Uralskogo nauchnogo tsentra Akademii nauk SSSR [Proceedings of the Institute of Plant and Animal Ecology of the Ural Scientific Centre of the USSR Academy of Sciences]. 1978;115:64-70. In Russian

33. Golovatin MG, Pashal'nyy SP, Zamyatin DO. Letnee naselenie ptits Dvuob'ya v 20042005 godah [The summer bird population of Dvuobye in 2004-2005]. Materialy $k$ rasprostraneniyu ptits na Urale, v Priural'e i Zapadnoy Sibiri - Materials on the bird distributions in the Urals, Cisurals and Western Siberia. 2004;9:69-75. In Russian

34. Loktionov EYu, Pilipenko DV, Yakovlev AA. Ptitsy priobskoy severnoy taygi [The birds of the northern taiga of the Ob River area]. Materialy $k$ rasprostraneniyu ptits na Urale, $v$ Priural'e i Zapadnoy Sibiri-Materials on the bird distributions in the Urals, Cisurals and Western Siberia. 2007;12:144-182. In Russian

35. Golovatin MG, Pashal'nyy SP. Ptitsy tsentral'noy chasti Dvuob'ya [The birds of the central part of Dvuobye]. Materialy $k$ rasprostraneniyu ptits na Urale, v Priural'e i Zapadnoy Sibiri - Materials on the bird distributions in the Urals, Cisurals and Western Siberia. 2008;13:26-30. In Russian

36. Pashal'nyy SP, Golovatin MG. Landshaftno-zonal'naya harakteristika naseleniya ptits poluostrova Yamal [The landscape-and-zone characteristics of the bird population of the Yamal Peninsula]. Yekaterinburg: Ural University Publ.; 2004. 79 p. In Russian

37. Mechnikova SA, Kudryavtsev NV, Luzan PI. Novye dannye o rasprostranenii i dinamike chislennosti nekotoryh redkih i malochislennyh ptits na yuge Yamala [New data on the distribution and population dynamics of some rare and scanty bird species in the south of Yamal]. Materialy $k$ rasprostraneniyu ptits na Urale, v Priural'e $i$ Zapadnoy Sibiri Materials on the bird distributions in the Urals, Cisurals and Western Siberia. 2005;10;209212. In Russian

38. Ekologiya Hanty-Mansiyskogo avtonomnogo okruga [The ecology of the Hanty-Mansiysk autonomous district]. Plotnikov VV, editor. Tyumen: SoftDizayn Publ.; 1997. 288 p. In Russian

39. Vengerov MP. Polovoy i vozrastnoy sostav vodoplavayushchih ptits nizhney Obi [The gender and age composition of the water birds of the Lower Ob River]. In: Materialy VI Vsesoyuznoy ornitologicheskoy konferentsii. Ch. 2 [Proc. of the VI All-Union Ornithological Conf. Pt. 2]. Moscow: Moscow State University Publ.; 1974. pp. 249-250. In Russian

40. Strel'nikov EG. Sostoyanie ornitofauny v Elizarovskom zakaznike letom 2001 goda [The state of the avifauna in the Elizarovskiy Wildlife Reserve in the 2001 summer]. Materialy k rasprostraneniyu ptits na Urale, v Priural'e i Zapadnoy Sibiri-Materials on the bird distributions in the Urals, Cisurals and Western Siberia. 2002;7:244-251. In Russian 
41. Sul'din MP. Ptitsy okrestnostey Nefteyuganska [Birds of Nefteyugansk surroundings]. Materialy $k$ rasprostraneniyu ptits na Urale, v Priural'e i Zapadnoy Sibiri - Materials on the bird distributions in the Urals, Cisurals and Western Siberia. 2003;8:176-193. In Russian

42. Strel'nikov EG, Strel'nikova OG. Kratkie kommentarii k rasprostraneniyu nekotoryh vidov ptits v basseyne Bol'shogo Yugana [Short comments on the distribution of some bird species in the Bolshoy Yugan River basin]. Materialy k rasprostraneniyu ptits na Urale, $v$ Priural'e $i$ Zapadnoy Sibiri-Materials on the bird distributions in the Urals, Cisurals and Western Siberia. 1998;3:173-180. In Russian

43. Bayanov ES. Nekotorye ptitsy Yarkovskogo rayona Tyumenskoy oblasti [Some birds of the Yarkovo district of Tyumen region]. Materialy $k$ rasprostraneniyu ptits na Urale, $v$ Priural'e i Zapadnoy Sibiri-Materials on the bird distributions in the Urals, Cisurals and Western Siberia. 2007;12:13-20. In Russian

44. Grazhdan KV. Ptitsy Tyumeni i Tyumenskogo rayona [Birds of Tyumen and Tyumen district]. Materialy $k$ rasprostraneniyu ptits na Urale, v Priural'e $i$ Zapadnoy Sibiri Materials on the bird distributions in the Urals, Cisurals and Western Siberia. 1998;3:4755. In Russian

45. Yudkin VA. Ptitsy podtaezhnyh lesov Zapadnoy Sibiri [The birds of the subtaiga forest of Western Siberia]. Novosibirsk: Nauka, Siberian Branch Publ.; 2002. 488 p. In Russian

46. Tarasov VV, Ryabitsev VK, Primak IV, Davydov AYu. Ptitsy Kazanskogo rayona Tyumenskoy oblasti [The birds of Kazanskoe district of Tyumen region]. Materialy $k$ rasprostraneniyu ptits na Urale, $v$ Priural'e i Zapadnoy Sibiri-Materials on the bird distributions in the Urals, Cisurals and Western Siberia. 2007;12:238-258. In Russian

47. Tarasov VV, Primak IV. K sostoyaniyu neohranyaemyh redkih vidov ptits Tyumenskoy oblasti [On the state of unprotected rare bird species of Tyumen region]. In: Materialy ko vtoromu izdaniyu Krasnoy knigi Tyumenskoy oblasti [Materials for the second edition of the Red Data Book of Tyumen region]. Tyumen: TyumenNIIgiprogaz Publ.; 2013. pp. 125144. In Russian

48. Yakimenko VV. Materialy k rasprostraneniyu ptits v Omskoy oblasti [Materials on the bird distribution in Omsk region]. Materialy k rasprostraneniyu ptits na Urale, $v$ Priural'e $i$ Zapadnoy Sibiri - Materials on the bird distributions in the Urals, Cisurals and Western Siberia. 1998;3:192-221. In Russian

49. Solov'ev SA. Ornitofauna goroda Omska i Omskogo rayona [The avifauna of Omsk city and Omsk district]. Materialy $k$ rasprostraneniyu ptits na Urale, v Priural'e i Zapadnoy Sibiri - Materials on the bird distributions in the Urals, Cisurals and Western Siberia. 2001;6:147-153. In Russian

50. Solov'ev SA. Ptitsy Omska i ego okrestnostey [The birds of Omsk and its surroundings]. Novosibirsk: Nauka, Siberian Branch Publ.; 2005. 296 p. In Russian

51. Solov'ev SA, Odintseva AA, Kolpakova TYu, Odintsev OA, Solov'ev FS, Yakovlev KA. Omsk [Omsk]. In: Ptitsy gorodov Rossii [The birds of Russian cities]. Moscow: Tovarishchestvo nauchnyh izdaniy KMK Publ.; 2012. pp. 331-360. In Russian

52. Moskvitin SS, Dubovik AD, Gord BYa. Ptitsy doliny r. Ket' [The birds of the Ket River valley]. In: Fauna i sistematika pozvonochnyh Sibiri [The fauna and taxonomy of the Siberian vertebrates]. Novosibirsk: Nauka, Siberian Branch Publ.; 1977. pp. 245-279. In Russian

53. Milovidov SP, Nehoroshev OG, Kuranov BD. Ornithocomplex of the South-Eastern part of the Vasyugan swamp (Tomsk Oblast, Russia). Vestnik Tomskogo gosudarstvennogo universiteta. Biologiya - Tomsk State University Journal of Biology. 2014;2(26):108-129. In Russian

54. Milovidov SP, Nehoroshev OG, Kuranov BD. Birds of the valleys of the Tom River tributaries (Tomsk oblast). Vestnik Tomskogo gosudarstvennogo universiteta. Biologiya - Tomsk 
State University Journal of Biology. 2015;4(32):91-106. doi: 10.17223/19988591/32/5 In Russian

55. Yurlov AK. Poganka krasnosheynaya Podiceps auritus (Linnaeus, 1758) [The Horned Grebe Podiceps auritus (Linnaeus, 1758)]. In: Krasnaya kniga Novosibirskoy oblasti. Zhivotnye, rasteniya $i$ griby [The Red Data Book of Novosibirsk region. Animals, plants, and fungi]. 2nd ed. Yudkin VA, Shaulo DN, editors. Novosibirsk: Arta Publ.; 2008. 111 p. In Russian

56. Zalesskiy IM,Zalesskiy PM. Ptitsy yugo-zapadnoy Sibiri (zoogeograficheskiy obzor s ukazaniyami novyh dannyh o rasprostranenii) [The birds of the southwest of Siberia (a zoogeographical survey with new data on the distribution]. Byulleten'MOIP. Otdelenie biologii - Bulletin of Moscow Society of Naturalists. Biological series. 1931;40(3/4):145-206. In Russian

57. Ruzskiy MD. Zoodinamika Barabinskoy stepi [The zoodynamics of the Barabinskaya steppe]. Trudy Tomskogo universiteta [Proceedings of Tomsk University]. 1946;97:17-68. In Russian

58. Yanushevich AI, Zolotareva OS. Vodoplavayushchaya dich' Baraby [The waterfowl of Baraba]. Novosibirsk: Krayizdat Publ.; 1947. 80 p.

59. Yurlov KT, Chernyshov VM, Koshelev AI, Sagitov RA, Totunov VM, Hodkov GI, Yurlov AK. Novye i redkie ptitsy v rayone ozera Chany (Zapadnaya Sibir') [New and rare birds in the Chany Lake area (Western Siberia)]. In: Migratsii ptits v Azii [Bird migrations in Asia]. Novosibirsk: Nauka, Siberian Branch Publ.; 1977. pp. 205-209. In Russian

60. Balatskiy NN. K avifaune ozera Karachinskogo (Baraba) [On the avifauna of Karachinskoe Lake (Baraba)]. Materialy k rasprostraneniyu ptits na Urale, $v$ Priural'e i Zapadnoy Sibiri - Materials on the bird distributions in the Urals, Cisurals and Western Siberia. 1998;3:511. In Russian

61. Zhukov VS. The short-toed Circaetus gallicus and imperial Aquila heliaca eagles and other rare birds in the north of Novosibirsk Oblast. Russkiy Ornitologicheskiy Zhurnal. 2012;21(792):2149-2161. In Russian

62. Vasil'chenko AA. K ornitofaune severo-vostoka Kemerovskoy oblasti [On the avifauna of Kemerovo region]. Materialy $k$ rasprostraneniyu ptits na Urale, $v$ Priural'e $i$ Zapadnoy Sibiri - Materials on the bird distributions in the Urals, Cisurals and Western Siberia. 2005;10:55-103. In Russian

63. Gagina TN, Skalon NV, Il'yashenko VB. Poganka krasnosheynaya, ili rogataya [The Horned Grebe]. In: Krasnaya kniga Kemerovskoy oblasti: T. 2. Redkie i nahodyashchiesya pod ugrozoy ischeznoveniya vidy zhivotnyh [The Red Data Book of Kemerovo region: Vol. 2. Rare and endangered animal species]. Skalon NV, editor. Kemerovo: Aziya print Publ.; 2012. pp. 94-96. In Russian

64. Belyankin AF. Ptitsy ravninnoy chasti Kemerovskoy oblasti (The birds of the plain part of Kemerovo region). Materialy $k$ rasprostraneniyu ptits na Urale, v Priural'e $i$ Zapadnoy Sibiri - Materials on the bird distributions in the Urals, Cisurals and Western Siberia. 1999;4:14-43. In Russian

65. Golovina NM. Gnezdyashchayasya avifauna vodohranilishch Kemerovskoy oblasti (Nevorob'inye) [The breeding bird fauna of water storage reservoirs of Kemerovo region (Non-passerines)]. Materialy $k$ rasprostraneniyu ptits na Urale, $v$ Priural'e i Zapadnoy Sibiri - Materials on the bird distributions in the Urals, Cisurals and Western Siberia. 2006;11:51-57. In Russian

66. Kotlov AA, Garms OYa. Spisok ptits Uglovskogo rayona Altayskogo kraya [A checklist of the birds of the Uglovskoe district of Altay region]. Materialy $k$ rasprostraneniyu ptits na Urale, $v$ Priural'e $i$ Zapadnoy Sibiri-Materials on the bird distributions in the Urals, Cisurals and Western Siberia. 2007;12:124-137. In Russian

67. Kotlov AA. K rasprostraneniyu redkih ptits na yugo-zapade Kulundy [On rare bird distribution in the southwestern surroundings of Kulunda]. Altayskiy Zoologicheskiy Zhurnal. 2015;9:69-71. In Russian 
68. Petrov VYu, Votinov AG. Krasnosheynaya poganka - Podiceps auritus (Linnaeus, 1758) [The Horned Grebe - Podiceps auritus (Linnaeus, 1758)]. In: Krasnaya kniga Altayskogo kraya. Redkie i nahodyashchiesya pod ugrozoy ischeznoveniya vidy zhivotnyh. T. 2 [The Red Data Book of Altay region. The rare and endangered animal species. Vol. 2]. Irisova NL, Shapet'ko EV, editors. Barnaul: Altay University Publ.; 2016. pp. 114-115. In Russian

69. Gribkov AV, Garms OYa, Ryabitsev VK, Ryabitsev AV. To avifauna of Sailugem mountain range and adjacent territories (South-Eastern Altai). Russkiy Ornitologicheskiy Zhurnal. 2010;19(593):1515-1561. In Russian

70. Mitrofanov OB. Nekotorye osobennosti raspredeleniya vodoplavayushchih na territorii Altayskogo zapovednika [Some characteristics of water bird distribution in the territory of the Altay Nature Reserve]. In: Problemy izucheniya i ohrany guseobraznyh ptits Vostochnoy Evropy $i$ Severnoy Azii. Tezisy dokladov I soveshchaniya rabochey gruppy po gusyam i lebedyam [Issues of the study and protection of the Anseriformes of Eastern Europe and Northern Asia. Abstr. of the reports of the I meeting of the Working Group on Geese and Swans (Moscow, Russia, 25-27 January, 2001]. Moscow. 2001. pp. 88-89. In Russian

71. Savchenko AP, Emel'yanov VI. Krasnosheynaya poganka [The Horned Grebe]. In: Krasnaya kniga Respubliki Hakasiya: Redkie i nahodyashchiesya pod ugrozoy ischeznoveniya vidy zhivotnyh [The Red Data Book of the Republic of Hakassia: Rare and endangered animal species]. Savchenko AP, editor. Krasnoyarsk; Abakan: Nauka Publ.; 2014. pp. 93-94. In Russian

72. Burskiy OV, Pagenkopf K, Vorstmayer V. Ptitsy Srednego Eniseya: annotirovannyy spisok vidov [The birds of the Middle Enisey: an annotated species list]. Materialy $k$ rasprostraneniyu ptits na Urale, $v$ Priural'e $i$ Zapadnoy Sibiri - Materials on the bird distributions in the Urals, Cisurals and Western Siberia. 2003;13:48-71. In Russian

73. Savchenko AP, Emel'yanov VI. Krasnosheynaya poganka [The Horned Grebe]. In: Krasnaya kniga Krasnoyarskogo kraya. T. 1. Redkie i nahodyashchiesya pod ugrozoy ischeznoveniya vidy zhivotnyh [The Red Data Book of Krasnoyarsk region. Vol. 1. Rare and endangered animal species]. Savchenko AP, editor. 3rd ed. Krasnoyarsk: Krasnoyarsk University Publ.; 2012. p. 51. In Russian

74. Rogacheva EV. Ptitsy Sredney Sibiri [The birds of Central Siberia]. Moscow: Nauka Publ.; 1988. 309 p. In Russian

75. Popov VV. Birds of Irkutsk region: species compound, spread and host way. Loon-Crane. Baykal'skiy Zoologicheskiy Zhurnal - Baikal Zoological Magazine. 2012;1(9):36-62. In Russian

76. Mel'nikov YuI. Key ornithological territory of the international value: the source and upper stream of Angara river. Baykal'skiy Zoologicheskiy Zhurnal - Baikal Zoological Magazine. 2010;1(4):41-46. In Russian

77. Sonina MV. The ecological-faunistic review of nesting birds of Irkutsk city. Baykal skiy Zoologicheskiy Zhurnal - Baikal Zoological Magazine. 2009;3:84-87. In Russian

78. Mel'nikov YuI, Tanichev AI, Zharov VA. Grebes of the middle stream of the Verhnjaja Angara, East Siberia. Russkiy Ornitologicheskiy Zhurnal. 1997;6(30):18-20. In Russian

79. Podkovyrov VA. Ocherk po biologii gagar i poganok yuga Vostochnoy Sibiri [An essay on the biology of the Loons and Grebes of Eastern Siberia]. In: Ornitologicheskie issledovaniya $v$ Rossii [Ornithological research in Russia]. 2000;2:120-147. In Russian

80. Gosudarstvennyy kadastr ob"ektov zhivotnogo mira v predelah Respubliki Buryatiya [State inventory of fauna objects within the borders of the Republic of Buryatia] [Electronic resource]. Available at: http://www.minpriroda-rb.ru/redbook/kadastr-obektov-zhivotnogomira.php?ELEMENT_ID=34265 (accessed 07.03.2017)

81. Verzhutskiy DB. Interesting meetings of bird in the Buryat Republic. Baykal'skiy Zoologicheskiy Zhurnal - Baikal Zoological Magazine. 2014;2(15):59-62. In Russian

82. Shkatulova AP. Materialy po ornitofaune Buryatskoy ASSR [Materials on the avifauna of the Buryatskaya ASSR]. Ornitologiya. 1979;14:97-107. In Russian 
83. Popov VV, Ananin AA. About ornitofauna of Eravninskie lakes and their outskirts (Buriatiya). Nonpasserine. Baykal'skiy Zoologicheskiy Zhurnal - Baikal Zoological Magazine. 2009;2:71-79. In Russian

84. Mironova VYe, Pyeryetolchina TA. Summer ornithophauna of the Ivan-Arakhl'yey lake system. Uchenye zapiski Zabaykal'skogo Gosudarstvennogo universiteta. Seriya: Estestvennye nauki - Scholarly Notes of Transbaikal State University. Biological Sciences. 2010;1:147-151. In Russian

85. Vorobyev KA. Ptitsy Yakutii [The birds of Yakutia]. Moscow: Academy of Sciences of the USSR Publ.; 1963. 336 p. In Russian

86. Maak RK. Vilyuyskiy okrug" Yakutskoy Oblasti. Ch. 2 [The Vilyuy district of Yakutsk region. Pt. 2]. St. Petersburg: Tipografiya i hromolitografiya A. Transhelya Publ.; 1886. 368 p. In Russian

87. Andreev BN. Ptitsy Vilyuyskogo basseyna [The birds of the Vilyuy River basin]. Yakutsk: Yakutsk Publ.; 1987. 192 p. In Russian

88. Vartapetov LG, Germogenov NI. The fauna structure and classification of bird communities from the middle Lena River valley. Journal of Zoology. 2013;92(1):77-86. doi: 10.7868/ S0044513413010133 In Russian

89. Krasnaya kniga Respubliki Saha (Yakutiya). T. 2: Redkie i nahodyashchiesya pod ugrozoy ischeznoveniya vidy zhivotnyh (nasekomye, ryby, zemnovodnye, presmykayushchiesya, ptitsy, mlekopitayushchie) [The Red Data Book of the Saha Republic (Yakutia). Vol. 2: Rare and endangered animal species (insects, fishes, amphibians, reptiles, birds, mammals]. Alekseev VG, editor. Yakutsk; 2003. 208 p. In Russian

90. Stegmann BK. Die Vogel des Dauro-mandschurischen Uebergangsgebietes. J. fur Ornithologie. 1930;78(4):389-471. In German

91. Dugintsov VA, Pan'kin NS. Spisok ptits Verhnego i Srednego Priamur'ya v administrativnyh granitsah Amurskoy oblasti [A bird checklist for the Upper and Middle Amur River area within the borders of Amur region]. In: Problemy ekologii verhnego Priamur'ya: Sbornik nauchnyh trudov [Ecological problems of the Upper Amur River area: Collected scientific works]. Blagoveshchensk; 1993. pp. 120-140. In Russian

92. Antonov AI, Parilov MP. K otsenke sovremennogo statusa ohranyaemyh vidov ptits na vostoke Amurskoy oblasti [On the evaluation of the current status of protected bird species in the east of the Amur region]. Amurskiy Zoologicheskiy Zhurnal - Amurian Zoological Journal. 2009;1(3):270-274. In Russian

93. Babenko VG. Ptitsy Nizhnego Priamur'ya [The birds of the Lower Amur River area]. Moscow: Prometey Publ.; 2000. 724 p. In Russian

94. Roslyakov AG. Krasnosheynaya poganka [The Horned Grebe]. In: Krasnaya kniga Habarovskogo kraya: Redkie i nahodyashchiesya pod ugrozoy ischeznoveniya vidy rasteniy $i$ zhivotnyh [The Red Data Book of Habarovsk region: Rare and endangered plant and animal species]. Ishaev VI, editor. Habarovsk: Priamurskie vedomosti Publ.; 2008. pp. 417418. In Russian

95. Nechaev VA. Krasnosheynaya poganka [The Horned Grebe]. In: Krasnaya kniga Amurskoy oblasti: Redkie i nahodyashchiesya pod ugrozoy ischeznoveniya vidy zhivotnyh, rasteniy $i$ gribov [The Red Data Book of Amur region: Rare and endangered animal, plant, and fungus species]. Kozhemyako ON, editor. Blagoveshchensk: Blagoveshchensk Pedagogical University Publ.; 2009. 52 p.

96. Tiunov IM, Blohin AYu. Rare and scarce birds of North Sahalin (new records). Russkiy Ornitologicheskiy Zhurnal. 2012;21(827):3192-3198. In Russian

97. Glushchenko YuN, Kal'nitskaya IN, Korobov DV. Ptitsy Lunsko-Nabil'skogo sektora SeveroVostochnogo Sahalina. Soobshchenie 1. Fonovoe naselenie [The birds of the Lunskiy and Nabil sector of the northeast of Sahalin. Report 1. The background population]. Amurskiy Zoologicheskiy Zhurnal - Amurian Zoological Journal. 2012;4(1):83-96. In Russian 
98. Blinovskaya YaYu, Bocharnikov VN. Ptitsy v ekosistemah morskogo poberezh'ya kak indikator chuvstvitel'nosti pribrezhno-morskoy zony $\mathrm{k}$ neftyanomu zagryazneniyu [Birds in sea coast ecosystems as indicators of the sensitivity of the sea coast zone to oil contamination]. In: Zashchita okruzhayushchey sredy $v$ neftegazovom komplekse [Environmental protection in oil and gas complex]. 2008;2:35-39. In Russian

99. Surmach N, Val'chuk O. Ptitsy Sahalina [The birds of Sakhalin]. Vladivostok: Apelsin Publ.; 2010. 156 p. In Russian

100. Andreev AV, Krechmar AV, Utehina IG. Ptitsy [Birds]. In: Rastitel'nyy i zhivotnyy mir zapovednika "Magadanskiy" [The flora and fauna of the Magadan Nature Reserve]. Magadan: the Northeast Scientific Centre of the Far East Branch of the Russian Academy of Sciences Publ.; 2011. pp. 129-155. In Russian

101. Krechmar AV. Gagary Gaviiformes i poganki Podicipitiformes kavinskoy ravninnoy lesotundry (severnoe Priohot'e) [Loons Gaviiformes and Grebes Podicipitiformes of the plain forest tundra in the Kava River area (the northern Ohotskoe Sea coast)]. Vestnik Severo-Vostochnogo nauchnogo tsentra DVoRAN - Bulletin of the North-East Scientific Center, Russia Academy of Sciences Far East Branch. 2013;1:60-68. In Russian

102. Kavinskaya ravnina i ozero Chukcha [The Kava plain and Chukcha Lake] [Electronic resource]. Available at: http://www.fesk.ru/wetlands/277.html (accessed 07.03.2017)

103. Andreev AV. Prirodnye usloviya uchastkov zapovednika [The natural conditions of the nature reserve parts]. In: Rastitel'nyy i zhivotnyy mir zapovednika "Magadanskiy" [The flora and fauna of the Magadan Nature Reserve]. Magadan: the Northeast Scientific Centre of the Far East Branch of the Russian Academy of Sciences Publ.; 2011. pp. 6-46. In Russian

104. Dorogoy IV. Vodoplavayushchie i drugie okolovodnye ptitsy okrestnostey Ol'skoy laguny [The waterfowl and other semi-aquatic birds of the vicinity of the Ola Lagoon]. Vestnik Severo-Vostochnogo nauchnogo tsentra DVoRAN - Bulletin of the North-East Scientific Center, Russia Academy of Sciences Far East Branch. 2008;4:45-62. In Russian

105. Dorogoy IV. Avifaunisticheskie nahodki na yuge Magadanskoy oblasti [Avifaunistic registrations in the south of Magadan region]. Vestnik Severo-Vostochnogo nauchnogo tsentra DVoRAN - Bulletin of the North-East Scientific Center, Russia Academy of Sciences Far East Branch. 2010;4:37-44. In Russian

106. Kamchatka: Spravochnik turista [Kamchatka: A tour guide]. Kirillov VI et al., editors. Petropavlovsk-Kamchatskiy: Dalnevostochnoe Publ.; 1994. 228 p. In Russian

107. Zavgarova YuR, Gerasimov YuN, Syroechkovskiy EE, Lappo EG, Helkvist A, Pal'mer F, Buhalova RV. Ptitsy okrestnostey poselka Il'pyrskogo (krayniy yugo-zapad Koryakskogo nagor'ya) [Birds of the Ilpyrskiy settlement surroundings (the extreme southwest of the Koryak highland)]. In: Biologiya i ohrana ptits Kamchatki [Biology and protection of birds in Kamchatka]. 2014;10:3-32. In

Received 21 February 2017; Revised 06 March 2017; Accepted 07 March 2017; Published 25 March 2017

\footnotetext{
Author info:

Tarasov Vladimir V, Cand. Sci. (Biol.), Assoc. Professor, Senior Researcher, Institute of Plant and Animal Ecology, Ural Branch of the Russian Academy of Sciences, 2028 Marta Str., Yekaterinburg 620144, Russian Federation.

E-mail: grouse@bk.ru
} 